\title{
Impact of Poly(L-lactide) versus Poly(L-Lactide-co-Trimethylene Carbonate) on Biological Characteristics of Fibroblasts and Osteoblasts*
}

\author{
Anna SCISLOWSKA-CZARNECKA, Elzbieta PAMULA, and Elzbieta KOLACZKOWSKA
}

Accepted November 22, 2012

\begin{abstract}
Scislowska-CZARnecka A., Pamula E., Kolaczkowska E. 2013. Impact of poly(L-lactide) versus poly(L-lactide-co-trimethylene carbonate) on biological characteristics of fibroblasts and osteoblasts. Folia Biologica (Kraków) 61: 11-24.

Bone tissue loss due to injury or disease often requires application of autologous tissue grafts or artificial biomaterials to fill the fracture. Synthetic biomaterials provide temporary structural support for bone tissue and can be subsequently colonized by host tissue-specific cells. One of the most investigated groups of biomaterials are degradable polymers that naturally decompose in tissues with time. In particular aliphatic polyesters such as polylactides were reported to fulfill biocompatibility requirements as they induce a minor or lack an immune response and integrate with the surrounding tissue. Here we report on the biological effects of two polymers: poly(L-lactide) (PLLA) and a copolymer of L-lactide and trimethylene carbonate (PLTMC) on osteoblasts (MG-63) and fibroblasts (L-929). Osteoblasts are bone forming cells that are in the closest contact with the potential implant while fibroblasts produce the stroma forming the extracellular matrix (ECM) and along with macrophages initiate inflammation. We detected that both types of cells adhered better to PLLA than to PLTMC which might be related to the more rough surface of the former. However, both polymers, but especially PLTMC, increased apoptotic death of both cell types. Moreover, in contrast to PLLA, PLTMC modulated the production of some immune-related mediators by fibroblasts: it increased nitric oxide production and synthesis of numerous pro-inflammatory factors, cytokines (TNF-a and IL-6) activating leukocytes, and ECM-degrading MMP-9 which facilitates leukocyte migration. Thus, overall, our data suggest that PLTMC is less cytocompatible than PLLA.
\end{abstract}

Key words: Biodegradable polymers, MG-63, L-9292, adhesion, cytokines, MMP-9.

Anna SCISLOWSKA-CZARNECKA, Department of Anatomy, Academy of Physical Education, Jana Pawla II 78, 31-571 Kraków. Poland.

E-mail:scis@poczta.onet.pl

Elzbieta PAMULA, Department of Biomaterials, AGH University of Science and Technology, A. Mickiewicza, 30 30-59 Kraków, Poland.

Elzbieta KOLACZKOWSKA, Department of Evolutionary Immunology, Jagiellonian University, Gronostajowa 9, 30-387 Kraków, Poland.

Bone tissue engineering is currently one of the fastest growing fields within regenerative medicine aimed at developing technology for successful and safe bone tissue replacement (LEWANDOWSKASZUMIEL \& WOJTOWICZ 2011). Different types of materials have been tested for bone tissue healing/repair. However, one of the revolutionary concepts in the field of biomaterials was the introduction of polymers intended to degrade within the body after temporarily serving as either (i) structural scaffolds, (ii) matrices for controlling drug release, or (iii) extracellular matrix substitutes controlling the regeneration of tissue (LENDLEIN et al.
2011; SHASTRI \& LENDLEIN 2009). One group of promising polymers are those derived from aliphatic polyesters. In particular, poly(L-lactide) (PLLA or polylactic acid) has a good record of safe use in humans and with a wide range of applications (CAMERON \& SHAVER 2011; PALM \& GOLDMAN 2009). While most PLLA properties are optimal, it also possesses some less favorable features, e.g. its degradation time in vivo is very long ( $>$ two years) and depends on the size of the device (PANG et al. 2011). Moreover, although numerous studies suggest that PLLA is sufficiently biocompatible (HOLLINGER 1983; NELSON et al. 
1977) there are some studies that suggest otherwise (VAN SLIEDREGT et al. 1994; VERHEYEN et al. 1993). Because of this there is a constant need for novel PLLA-based polymers with improved properties and of potential clinical and commercial application. Poly(trimethylene carbonate) (PTMC) is an elastomeric material used in biomedical applications (GUNATILLAKE et al. 2006), although similarly to the majority of aliphatic polycarbonates, it becomes soft in the temperature range $40-60^{\circ} \mathrm{C}$ and has rather weak mechanical properties. However, one of the important advantages of PTMC is its degradation products - diols which are less acidic than lactic acid produced as a result of PLLA hydrolytic degradation (GUNATILLAKE et al. 2006; ZHANG et al. 2006). It was already shown that copolymerization of L-lactide with trimethylene carbonate resulted in materials with tunable hydrolytic degradation depending on the molar ratio of both components and parameters of the synthesis including temperature and time (HUA et al. 2009). This opens the possibility of producing novel biocompatible polymers with degradation kinetics better adjusted to bone tissue healing and regeneration. In the work presented here we tested if a copolymer of L-lactide and trimethylene carbonate (PLTMC) will show improved cytocompatibility as compared to the initial homopolymer of L-lactide (PLLA) as evidenced by weaker body cell activation and a lower mediator release.

In particular, we tested the impact of PLLA and PLTMC on two cell populations, fibroblasts and osteoblasts. Fibroblasts are major stromal/connective tissue cells, providing structural support for tissues and producing extracellular matrix (ECM) (ENZERINK \& VAHERI 2011). On the other hand, osteoblasts are specialized fibroblasts that in addition to fibroblastic products express e.g. bone sialoprotein, osteocalcin, osteonectin, osteopontin and secrete bone-matrix proteins, thus promoting bone mineralization (CAETANO-LOPES et al. 2009). Despite the fact that both cell types synthesize ECM, they are also capable of its degradation via matrix metalloproteinases (MMP) the release of which allows for tissue remodeling. Fibroblasts and osteoblasts are also recognized as cells capable of cytokine (both pro- and anti-inflammatory) and chemokine synthesis that can trigger inflammation and activate leukocytes (CAETANO-LOPES et al. 2009; YASZAY et al. 2001).

In the current study we used two reference cell lines: mouse L-929 fibroblasts and human MG-63 osteoblasts, and we evaluated cell viability (including an assessment of apoptosis), adherence, and synthesis of nitric oxide (NO), proteins (in total), and especially of cytokines/chemokines, and matrix metalloproteinase 9 (MMP-9).
Overall our data indicate that although both polymers are moderately cytotoxic (induction of cell apoptosis), it is PLTMC that is more immunogenic than PLLA towards fibroblasts and osteoblasts. Therefore our in vitro studies show that the copolymerization of L-lactide with trimethylene carbonate might not result in polymeric material with improved cytocompatibility towards the two cell types. This issue is discussed in the light of previous PLTMC cytocompatibility studies on different cell types.

\section{Material and Methods}

\section{Synthesis of polymers}

A copolymer of L-lactide and trimethylene carbonate (PLTMC, 50:50) was synthesized by ringopening polymerization of L-lactide (Purasorb L, Purac, The Netherlands) and 1,3-trimethylene carbonate (Boehringer Ingelheim, Germany), in the presence of low-toxic initiator $\mathrm{Zr}(\mathrm{acac})_{4}$ (Aldrich, Germany) - at a molar ratio of $1.25 \times 10^{-3}$ at $100^{\circ} \mathrm{C}$ by a conventional method using a vacuum line for degassing and sealing of the ampoules, as described previously in detail (DOBRZYNSKI et al. 2006; SCISLOWSKA-CZARNECKA et al. 2012). The synthesized PLTMC had an average molecular weight of $65 \mathrm{kDa}$, polydispersity index (d) of 1.8 , and the following molar ratios of comonomers in the copolymer: expected $\left(\mathrm{N}_{\mathrm{e}}=50: 50\right)$ and as determined by ${ }^{1} \mathrm{H}$ NMR $\left(\mathrm{N}_{\mathrm{m}}=52: 48\right)$ (SCISLOWSKA-CZARNECKA et al. 2012).

Poly-L-Lactide (PLLA) with a viscosity-average molecular weight $\mathrm{M}_{\mathrm{v}}$ of $410 \mathrm{kDa}$ was purchased from Purac (The Netherlands). The chemical structure of the two polymers is presented in Fig. 1.

The PLLA and PLTMC foils were cast from a $10 \%(\mathrm{w} / \mathrm{v})$ polymer solution in methylene chloride (POCh, Gliwice, Poland) on glass Petri dishes, followed by air drying for $24 \mathrm{~h}$ and vacuum drying for the next $72 \mathrm{~h}$. Then, the foils were rinsed with ultra high purity water (UHQ-water of the resistivity of $18.2 \mathrm{M} \Omega \mathrm{cm}$, produced by Purelab UHQ, Elga, UK) for $12 \mathrm{~h}$. UHQ-water was exchanged 6 times. Afterwards, the foils were air and vacuum dried for $24 \mathrm{~h}$ and $72 \mathrm{~h}$, respectively. The resulting foils had a thickness of $0.18 \mathrm{~mm}$. For all experiments the bottom surface of the foils, contacting the glass during the preparation process, was used.

Detailed characteristics of the materials were published previously SCISLOWSKA-CZARNECKA et al. 2012) and included: composition of copolymers, molecular weights, thermal properties (glasstransition temperature $\left(T_{g}\right)$ and melting temperature $\left.\left(T_{m}\right)\right)$, surface chemical composition, contact angles, 


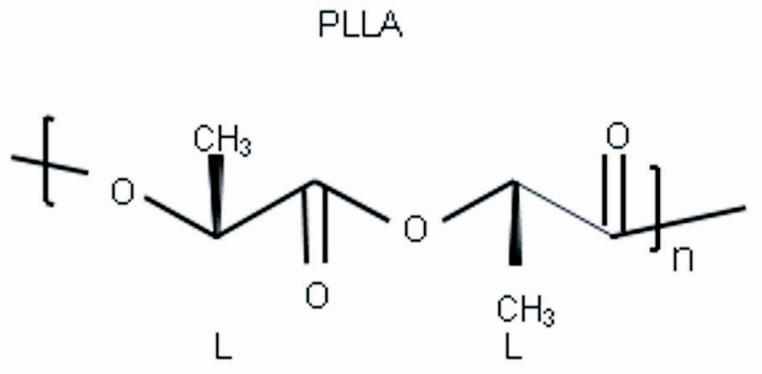

PLTMC

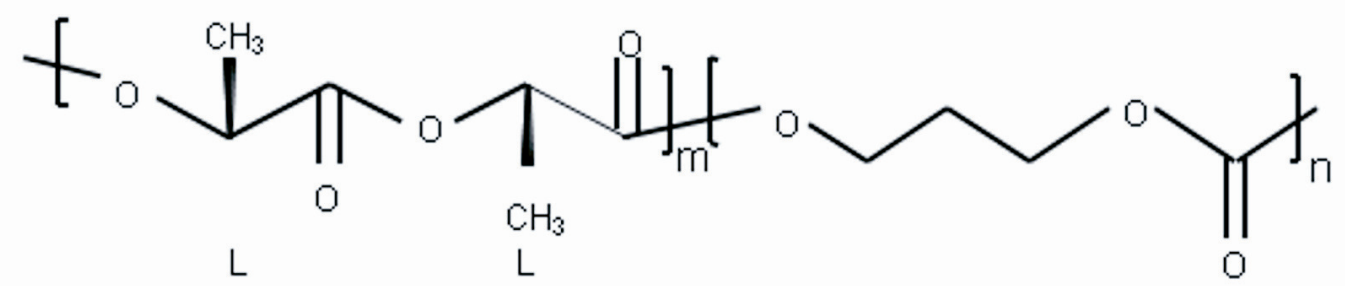

Fig. 1. Chemical structure of poly(L-lactide) (PLLA) and poly(L-lactide-co-trimethylene carbonate) (PLTMC).

surface free energies (SFEs), topography measurements, average roughness $\left(\mathrm{R}_{\mathrm{a}}\right)$. In brief, both polymers were semicrystalline with $T_{g}=92.5^{\circ} \mathrm{C}$ and $T_{m}=199.5^{\circ} \mathrm{C}$ for PLLA and $T_{g}=30.7^{\circ} \mathrm{C}$ and $T_{m}=149.8^{\circ} \mathrm{C}$ for PLTMC. Wettability studies showed that the polymers had similar values of total surface free energy. Topography analysis by atomic force microscopy revealed that the foils were quite textured, especially PLLA, where typical spherulitic structures were observed. As a result, the average roughness of PLLA and PLTMC was relatively high, i.e. $160 \pm 12 \mathrm{~nm}$ and $36 \pm 11.5 \mathrm{~nm}$, respectively (SCISLOWSKA-CZARNECKA et al. 2012).

\section{Cell cultures}

The murine fibroblast L-9292 and human osteoblast MG-63 cell lines were used in the studies. The cells were cultured in $75 \mathrm{ml}$ plastic bottles (Nunc, Denmark) in DMEM culture medium enriched with glucose, L-Glutamine (PAA, Austria), $10 \%$ foetal bovine serum (PAA, Austria) and 5\% antibiotic solution containing penicillin $10 \mathrm{UI} / \mathrm{ml}$ and streptomycin $10 \mathrm{mg} / \mathrm{ml}$ (PAA, Austria). The cells were cultured in an incubator (Nuaire, USA) at $37^{\circ} \mathrm{C}$ and $5 \%$ of $\mathrm{CO}_{2}$. Every $2-3$ days, when the cells were forming high confluence monolayers, the cell cultures were passaged by trypsinization
$(0.25 \%$ solution of trypsin; Sigma-Aldrich, Germany).

\section{In vitro cell-biomaterial studies}

For cell culture studies the polymeric foils were washed in $70 \%$ ethanol, sterilized with UV irradiation (45 min for each side) and placed at the bottom of 24-well dishes (Nunc, Denmark). The cells that were harvested after 7 to 10 passages were counted in Bürker's hemocytometer, diluted to $3 \times 10^{4}$ cell/ml, and placed in the wells of 24-well culture dishes containing discs of the tested biomaterials. Tissue-culture polystyrene (TCPS; Nunc, Denmark) was used as a control material. Under these conditions the cells were cultured for 3 or 5 days. Subsequently, the morphology of cells adhering to the polymeric foils was observed under an inverted microscope (Jenamed, Germany) and was further verified by the crystal violet staining test. Alternatively, the ratio of apoptotic and/or necrotic cells was estimated. The supernatants were collected and frozen at $-20^{\circ} \mathrm{C}$ prior to further analyzes of inflammatory mediator content. Data from 3 independent experiments were averaged and reported.

\section{Cell adherence and proliferation}

The ability of the cells to adhere to TCPS or polymeric surfaces was tested using the crystal 
violet test $(\mathrm{CV})$. The cells adhering to the tested materials were fixed with $2 \%$ paraformaldehyde for $1 \mathrm{~h}$, and then stained with crystal violet $(\mathrm{CV}$ $0.5 \%$ in $20 \%$ methanol, for $5 \mathrm{~min}$ ). Afterwards the wells were washed with water and their content was transferred to a new 24-well culture plate. After drying, the absorbed dye was extracted by the addition of $1 \mathrm{ml}$ of $100 \%$ methanol (POCh, Gliwice, Poland). The optical density (O.D.) was measured at $570 \mathrm{~nm}$ with the Expert Plus spectrophotometer (Asys Hitach, Austria). Since the polymers absorb some crystal violet, additional controls containing polymeric foils and cell-free medium were run. The O.D. results from these controls were subtracted from the experimental data.

\section{Cell apoptosis and necrosis}

Apoptotic cells were identified quantitatively using the Annexin V-PE Apotosis Detection Kit I (BD Pharmingen, USA) that enables cell staining with Annexin V and 7-Amino-actinomycin (7-AAD). Annexin $\mathrm{V}$ binds to phosphatidylserine exposed on the outer leaflet of the plasma membrane of apoptotically dying cells while 7-AAD is a vital dye that enters all dead cells. The cells detached by trypsinization from polymers were stained with the kit according to the established protocol (KOLACZKOWSKA et al. 2009; KOLACZKOWSKA et al. 2009a). Briefly, the cells were washed twice with cold PBS and resuspended in binding buffer $(0.1 \mathrm{M}$ HEPES/NaOH (pH 7.4), $1.4 \mathrm{M} \mathrm{NaCl}, 25 \mathrm{mM}$ $\mathrm{CaCl}_{2}$ ). Then $2.5 \mu \mathrm{l}$ of Annexin V-PE and $2.5 \mu \mathrm{l}$ of 7 -AAD were added to the cells $\left(10^{5}\right.$ cells $/ 100 \mu$ l binding buffer) and incubated for $15 \mathrm{~min}$ at room temperature in the dark. Measurements were performed by a flow cytometer using CellQuest software (FACS Caliber; Becton Dickinson). The Annexin V-PE signal was measured in FL-2 and the 7-AAD in FL-3 channels. Dying cells were distinguished on the basis of the FL-2/FL-3 signals: early apoptotic Annexin $\mathrm{V}^{+} / 7-\mathrm{AAD}^{-}$; late apoptotic Annexin $\mathrm{V}^{+} / 7-\mathrm{AAD}^{+}$; necrotic cells Annexin $\mathrm{V}^{-} / 7-\mathrm{AAD}^{+}$; alive cells Annexin $\mathrm{V}^{-} / 7-\mathrm{AAD}^{-}$.

\section{Inflammatory mediators in cell supernatants}

\section{Determination of nitrite/nitrate}

The total amount of $\mathrm{NO}\left(\mathrm{NO}_{2}{ }^{-}\right.$and $\left.\mathrm{NO}_{3}{ }^{-}\right)$was measured as described previously (KOLACZKOWSKA et al. 2008). Briefly, nitrate was reduced to nitrite by addition of nitrate reductase, FAD and NADPH (all from Sigma-Aldrich, Germany) and then NADPH was oxidized by lactate dehydrogenase in the presence of sodium pyruvate (both from Sigma-Aldrich, Germany). Finally, nitrite concentration in the samples was measured by the Griess reaction, by adding Griess reagents $(0.1 \%$ naphthalethylenediamine dihydrochloride in $\mathrm{H}_{2} \mathrm{O}$ and $1 \%$ sulphanilamide in $5 \%$ concentrated $\mathrm{H}_{3} \mathrm{PO}_{4} ; 1: 1$ $\mathrm{vol} / \mathrm{vol}$ ) in a ratio of $1: 1$ to samples and standards. Sodium nitrite solution was used as an internal control for the Griess assay and $\mathrm{NaNO}_{3}$ (both from Sigma-Aldrich, Germany) as controls for the reduction step. The NO levels were measured at $540 \mathrm{~nm}$ with a Expert Plus spectrophotometer (Asys Hitech, Eugendorf, Austria).

\section{Determination of protein concentration}

Protein concentration in the supernatants collected from cell cultures was measured by the colorimetric BCA method. A mixture of copper (II) sulfate solution (CS, Sigma-Aldrich, Germany) and bicinchoninic acid solution (BCA; Sigma, Germany) in a ratio of 1:50 was first prepared. Subsequently, $10 \mu$ of each tested sample was transferred to wells of a 96-well plate and then $200 \mu$ l of the CS/BCA mixture was added. The plates were incubated for $30 \mathrm{~min}$ in the dark. The optical density was measured at $570 \mathrm{~nm}$ with an Expert Plus spectrophotometer (Asys Hitach, Austria).

\section{MMP-9 activity: gelatin zymography}

Zymography was performed as described before (KOLACZKOWSKA et al. 2006). Briefly, samples of supernatant were normalized for protein concentration. Then the exudates were electrophoresed in 10\% SDS-polyacrylamide gels, containing $1 \%$ porcine gelatin, (Sigma-Aldrich, Germany) with non-reducing conditions. The gels were washed twice in $2.5 \%$ Triton $\mathrm{X}-100$ (15 min each) and developed overnight at $37^{\circ} \mathrm{C}$ in incubation buffer (50 mM Tris- $\mathrm{HCl}, \mathrm{pH} 8.0,5 \mathrm{mM} \mathrm{CaCl}, 0.02 \%$ $\mathrm{NaN}_{3}, 1 \mu \mathrm{M} \mathrm{ZnCl}_{2}$ ). The gels were fixed and stained with $0.5 \%$ Coomassie brilliant blue (SigmaAldrich, Germany) in acetic acid/isopropanol/distilled water 1:3:6, and then washed in equilibrating solution with $40 \%$ methanol, $10 \%$ acetic acid and $3 \%$ glycerol (all from Sigma-Aldrich, Germany). Protein bands with gelatinolytic activity appeared as clear lysis zones within the blue background of the gelatin gel. The degradation of gelatin was visualized under long wave UV light. A pre-stained broad range molecular weight standard (Bio-Rad, USA) was used. Densitometric analysis of protein bands was performed through the use of the UVISoft-UVIMap program (UVItec, Ltd.,UK).

\section{Determination of cytokines/chemokines} by Cytometric Bead Array (CBA)

Cytometric Bead Array sets (Mouse Inflammation Kit and Human Inflammatory Cytokines Kit, CBA; BD Biosciences) were used to study cytoki- 
nes and chemokines in supernatants as described before (KOLACZKOWSKA et al. 2008). A mouse inflammation kit simultaneously detects mouse IL-6, IL-10, MCP-1, IFN- $\gamma$, TNF- $\alpha$, and IL-12p70 and the human kit identifies IL-8, IL-1 $\beta$, IL-6, IL-10, TNF- $\alpha$, IL-12p70. Both kits were used according to the manufacturer's instructions. Briefly, a mixture of 6 capture bead populations $(50 \mu l)$ with distinct fluorescence intensities (detected in FL3) coated with antibodies specific for the above cytokines/chemokines was mixed with each sample/standard $(50 \mu \mathrm{l})$. Additionally, PE-conjugated detection antibodies (detected in FL-2; $50 \mu$ l) were added to form sandwich complexes. After the 2-h incubation (in the dark) the samples were washed once (200 g, $5 \mathrm{~min}$ ) and resuspended in $300 \mu \mathrm{l}$ of wash buffer before acquisition on a FACScan cytometer (FACSCalibur flow cytometer, Becton Dickinson, USA). Following acquisition of data by two-colour cytometric analysis, the sample results were analysed using CBA software (BD Biosciences, USA). Standard curves were generated for each cytokine using the mixed cytokine/chemokine standard provided by the kit. The concentration of each cytokine in cell supernatants was determined by interpolation from the corresponding standard curve.

\section{Statistical analysis}

Results are expressed as means \pm SE. Statistical significance was determined by one way analysis of variance (ANOVA) followed by a post hoc T-Tukey test and the differences were regarded as significant at $p<0.05$. At the beginning of each experiment the cell numbers were the same $\left(3 \times 10^{4} / \mathrm{ml}\right.$ in each well). However, upon incubation of cells with some of the tested polymers their numbers significantly changed in time and this is reflected by changes in numbers of adhering cells (Fig. 1A, Fig. 1B) as fibroblasts and osteoblasts must adhere in order to survive (ANSELME 2000). Therefore, the levels of released inflammatory mediators might be a direct consequence of changes in cell numbers, thus all data were recalculated to cell adherence results (parameter/cell adherence). A letter-code on the figures is used to show statistically significant differences according to ANOVA. Letters ( $a, b, c$ or A, B, C) express statistical significance and are randomly chosen. The letter-code should be understood as follows: the values that are significantly different according to ANOVA are marked with different letters (e.g. "a" and "b" ; " $A$ " and "B") while the values sharing the same letter (e.g. "a" and "ab", "a" and "a") are similar, i.e. not statistically different. Differences between day 3 and 5 are significant at $\mathrm{P}<0.05$ according to the $\mathrm{T}$ test.

\section{Results}

\section{Cell adhesion/proliferation}

On days 3 and 5 of experiments MG-63 osteoblasts cultured on PLLA showed increased adherence in comparison to cells cultured on control TCPS (Fig. 2A). This effect was not observed in the case of PLTMC (Fig. 2A). L-929 fibroblasts incubated with PLTMC for 3 days showed significantly lower numbers of adhering cells while 5-day incubation with PLLA led to significantly increased fibroblast adherence in comparison to the control TCPS (Fig. 2B). In the case of all three tested biomaterials the osteoblast and fibroblast adherence increased in time and was higher on day 5 than on day 3 .

\section{Apoptotic cells}

In comparison to TCPS a significantly higher ratio (percentage) of early apoptotic cells was observed on days 3 and 5 when osteoblasts (Fig. 3A) and fibroblasts (Fig. 3B) were incubated with either PLLA or PLTMC. The ratio of late apoptotic cells was unaltered in comparison to TCPS. Moreover, we did not detect significant differences in numbers of necrotic osteoblasts and fibroblasts among cells incubated on the control material and on PLLA or PLTMC (data not shown).

\section{Protein content}

Osteoblasts co-cultured with PLLA for 5 days, and with PLTMC for 3 or 5 days, released significantly less proteins than the cells incubated with the control TCPS (Table 1 left upper panel). Statistical analysis showed that on both days of fibroblast incubation with PLTMC an increased secretion of proteins was detected in comparison to the control. On the other hand, co-culture of fibroblasts with PLLA increased secretion on day 3 but decreased protein release on day 5 (Table 1 right upper panel).

\section{Nitric oxide production}

Release of (NO) from osteoblasts was decreased on day 3 in the presence of PLTMC and on day 5 in the presence of both polymers (Table 1 left lower panel). Culturing of fibroblasts on PLTMC increased production of $\mathrm{NO}$ in comparison to the control on days 3 and 5, while incubation with PLLA decreased production of NO (Table 1 right lower panel). 

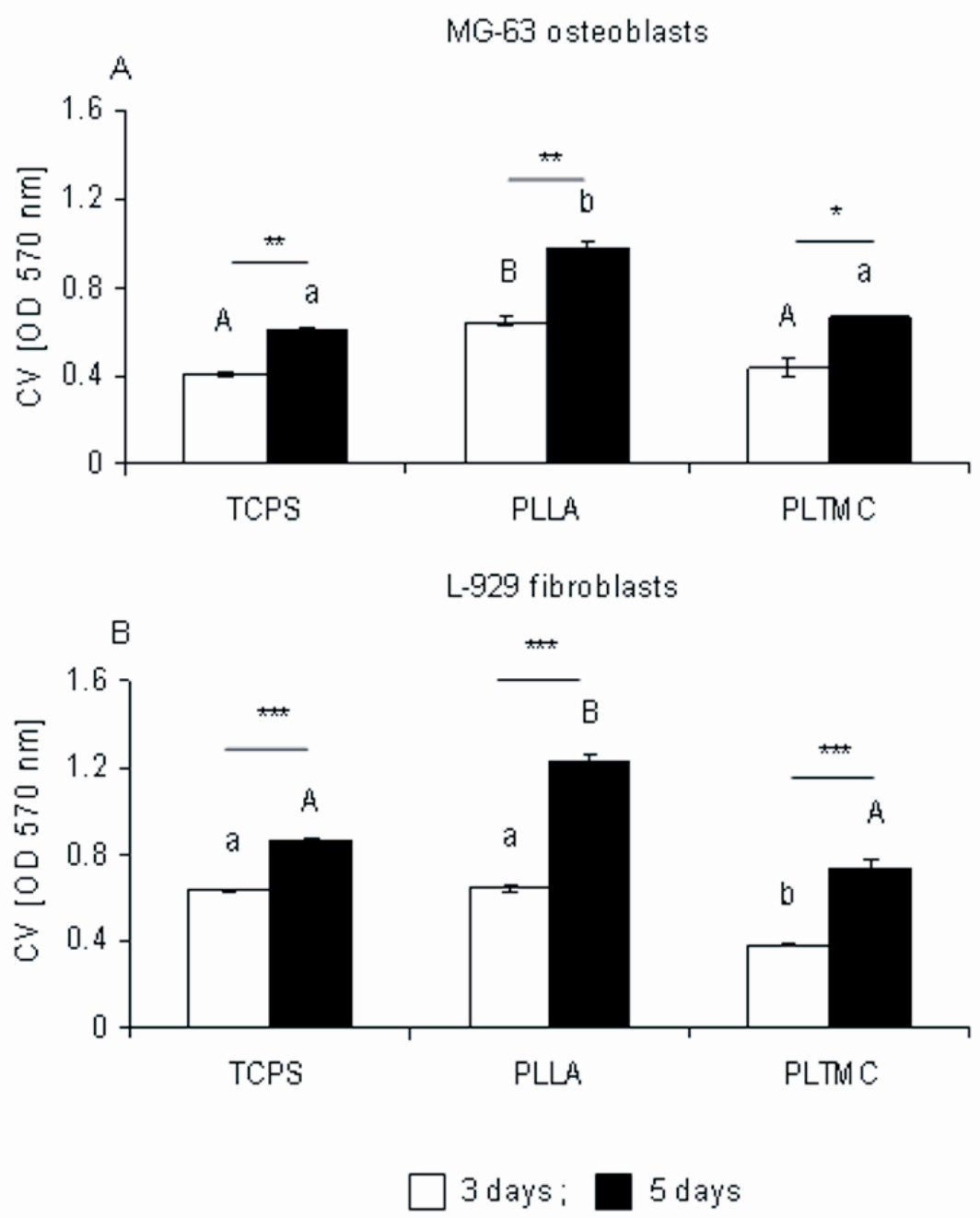

Fig. 2. Effects of polymers on adherence of osteoblasts MG-63 and fibroblasts L-929. Cell adherence of (A) MG-63 and (B) L-929 on tissue culture polystyrene (control) and on polymers: poly(L-lactide) (PLLA), poly(L-lactide-co-trimethylene carbonate) (PLTMC) after 3- and 5-day culture. The results are presented as means SE (data from 3 independent experiments). Different letters (e.g. A versus $\mathrm{B}$ or a versus $\mathrm{b}$ ) indicate statistically significant differences between the groups according to ANOVA. Asterisks indicate statistical differences between day 3 and $5 * \mathrm{P}<0.05 ; * * \mathrm{P}<0.01$.

MMP-9 release and activation

On day 3 of experiments osteoblasts cultured on PLLA and PLTMC showed unchanged production of pro-MMP-9 and MMP-9 (Fig. 4A). However, 5 -day cultures of osteoblasts in the presence of both investigated polymers significantly decreased pro-MMP-9 levels, while the levels of active MMP-9 were unchanged (Fig. 4A).

In comparison to TCPS, production of proMMP-9 and active MMP-9 by fibroblasts cultured on PLTMC was enhanced on day 3 (Fig. 4B). No MMP-9 production by fibroblasts was detected on day 5 in any group.

\section{Cytokine levels}

\section{Cytokine production by MG-63}

In comparison to the control (TCPS) the secretion of pro-inflammatory TNF- $\alpha$ by osteoblasts cultured with the PLLA and PLTMC was decreased on days 3 and 5 (Fig. 5A) while that of IL-6 (Fig. 5C) and IL-8 (Fig. 5E) was lower on day 5. On day 3 MG-63 cells cultured on both tested polymers showed decreased production of IL- $1 \beta$, while on day 5 PLTMC increased levels of IL-1 $\beta$ (Fig. 5B). Synthesis/release of IL-12p70 by MG-63 was decreased by PLTMC and PLLA on 


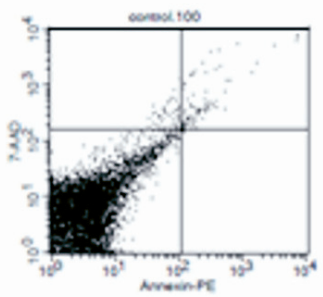

A
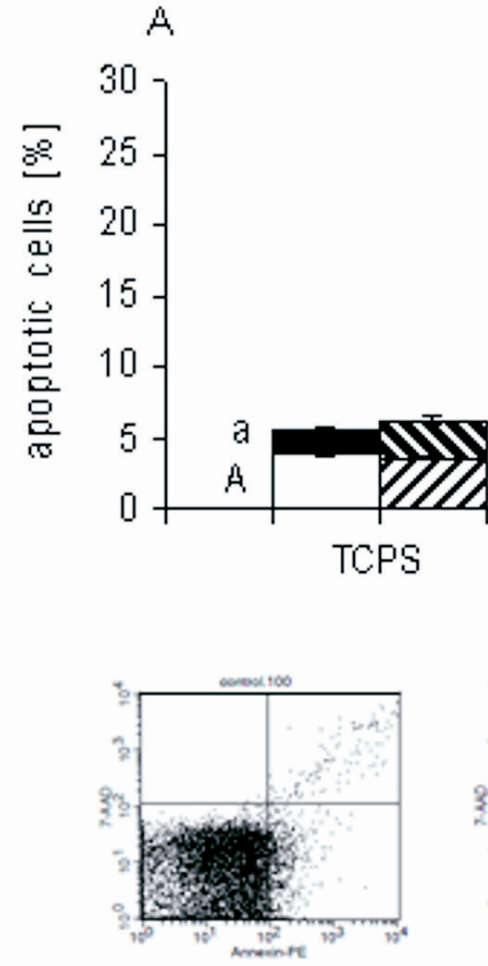

$\mathrm{B}$
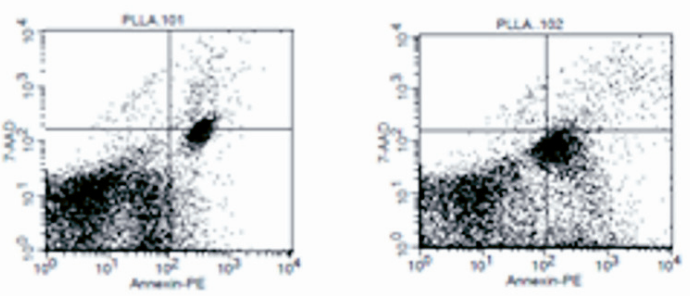

MG-63 osteoblasts

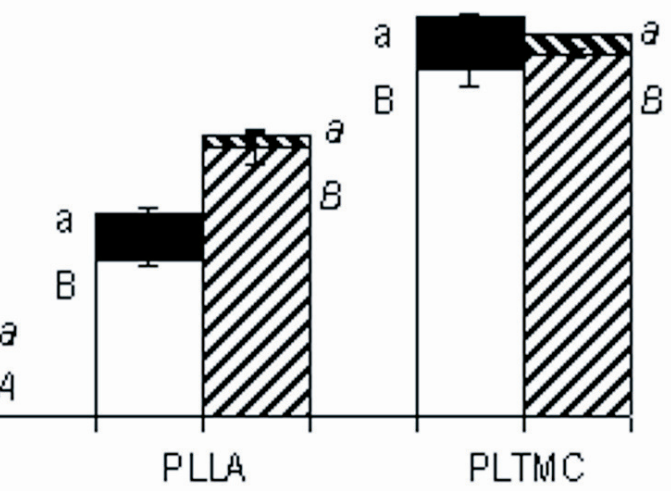

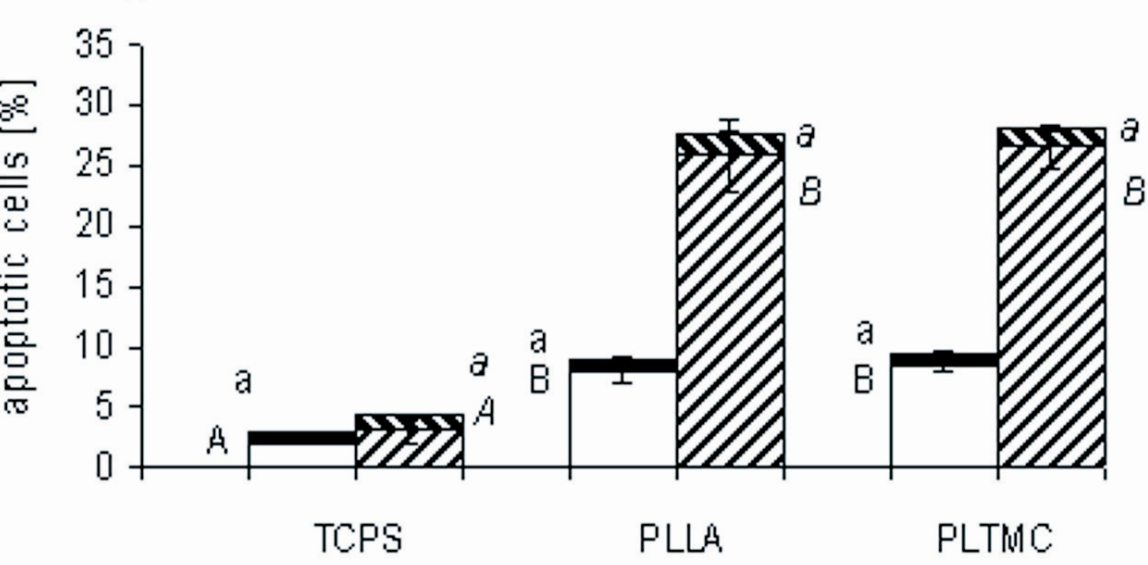

early apoptosis: $\square 3$ days, 5 days; late apoptosis: $\square 3$ days, 5 days

Fig. 3. Cell death by apoptosis of MG-63 osteoblasts and L-929 fibroblasts in the presence of the tested polymers. Numbers of apoptotic cells (at the early and late stages of apoptosis) (A) MG-63 cells and (B) L-929 cells incubated on tissue culture polystyrene (control) and on polymers: poly(L-lactide) (PLLA) and poly(L-lactide-co-trimethylene carbonate) (PLTMC) for either 3 or 5 days. Representative dot blots for day 3 are presented above the figures. The results are presented as means SE (data from 3 independent experiments). Different letters (e.g. A versus $\mathrm{B}$, a versus b on day 3 or $A$ versus $\mathrm{B}$, a versus $\mathrm{b}$ on day 5 ) indicate statistically significant differences between the groups according to ANOVA. 

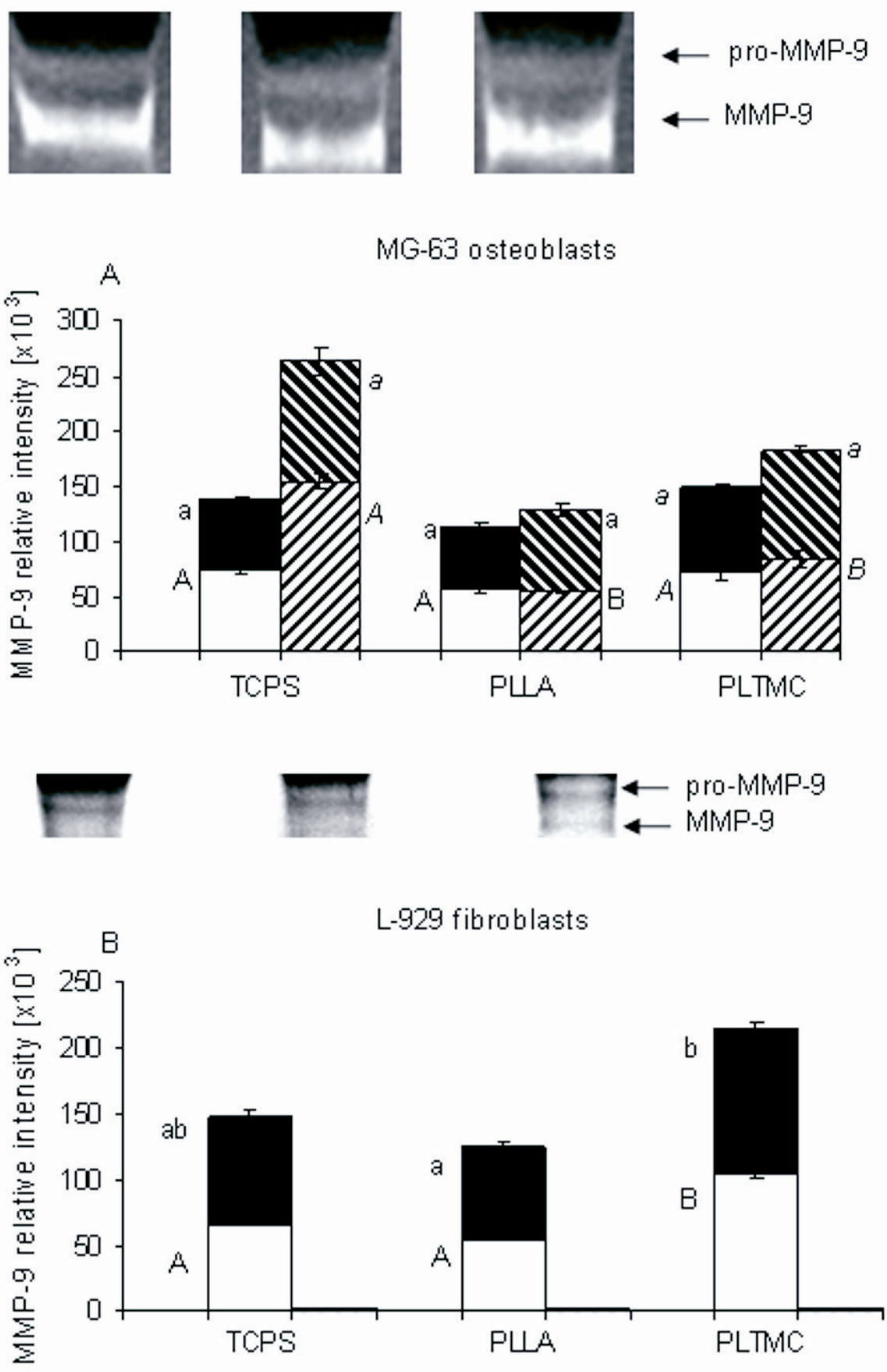

pro-MMP 9: $\square 3$ days, 5 days; active MMP 9: $\square 3$ days, $\mathbb{\mathbb { N }} 5$ days

Fig. 4. Release of pro-MMP-9 zymogen and its activation to MMP-9 by osteoblasts MG-63 and fibroblasts L-929 in the presence of the tested polymers. Relative expression of pro- and active MMP-9 released from (A) MG-63 and (B) L-929 cells cultured on control tissue culture polystyrene (control) and on polymers: poly(L-lactide) (PLLA) and poly(L-lactide-co-trimethylene carbonate) (PLTMC) for 3 or 5 days. Representative gel images for day 5 are presented above figures. The results are presented as means SE (data from 3 independent experiments). Different letters (e.g. versus b or A versus $\mathrm{B}$ ) indicate statistically significant differences between the groups according to ANOVA. 
Table 1

Production/release of proteins (total amount) and nitric oxide (NO) by MG-63 osteoblasts or L-929 fibroblasts in the presence of the tested polymers. PLLA: poly-L-lactide, PLTMC: poly(L-lactide-co-trimethylene carbonate), TCPS: tissue culture polystyrene (control). Levels of NO and total protein content were measured in supernatants collected from osteoblasts (MG-63) and fibroblasts (L-929) cultured in the presence of the polymers for either 3 days or 5 days. Asterisks indicate statistical significance from the control group (TCPS) at $* \mathrm{P}<0.05 ; * * \mathrm{P}<0.01$

\begin{tabular}{|c|c|c|c|c|c|}
\hline \multirow{2}{*}{\multicolumn{2}{|c|}{$\begin{array}{c}\text { Time } \\
\text { Material }\end{array}$}} & \multicolumn{2}{|c|}{ MG-63 } & \multicolumn{2}{|c|}{ L-929 } \\
\hline & & \multirow{2}{*}{$\begin{array}{c}3 \text { days } \\
1.729 \pm 0.036\end{array}$} & \multirow{2}{*}{$\begin{array}{c}5 \text { days } \\
0.889 \pm 0.009\end{array}$} & \multirow{2}{*}{$\begin{array}{c}3 \text { days } \\
0.796 \pm 0.031\end{array}$} & \multirow{2}{*}{$\begin{array}{c}5 \text { days } \\
0.623 \pm 0.012\end{array}$} \\
\hline$\frac{n}{2}$ & TCPS & & & & \\
\hline$\stackrel{0}{\Xi}$ & PLLA & $1.03 \pm 0.015$ & $\begin{array}{c}0.561 \pm 0.007 \\
*\end{array}$ & $\begin{array}{c}0.88 \pm 0.055 \\
* *\end{array}$ & $0.422 \pm 0.014$ \\
\hline$\stackrel{0}{2}$ & PLTMC & $\begin{array}{c}1.507 \pm 0.019 \\
* *\end{array}$ & $\underset{* *}{0.778 \pm 0.012}$ & $\begin{array}{c}1.414 \pm 0.069 \\
*\end{array}$ & $\begin{array}{c}0.735 \pm 0.007 \\
* *\end{array}$ \\
\hline $\bar{a}$ & TCPS & $0.132 \pm 0.001$ & $0.079 \pm 0.001$ & $0.068 \pm 0.002$ & $0.056 \pm 0.001$ \\
\hline$\frac{0}{0}$ & PLLA & $0.076 \pm 0.001$ & $\underset{* *}{0.047 \pm 0.001}$ & $\begin{array}{c}0.065 \pm 0.001 \\
* *\end{array}$ & $\begin{array}{c}0.042 \pm 0.001 \\
* *\end{array}$ \\
\hline o & PLTMC & $\begin{array}{c}0.119 \pm 0.001 \\
* *\end{array}$ & $\begin{array}{c}0.069 \pm 0.001 \\
*\end{array}$ & $\begin{array}{c}0.116 \pm 0.001 \\
*\end{array}$ & $\begin{array}{c}0.065 \pm 0.001 \\
*\end{array}$ \\
\hline
\end{tabular}
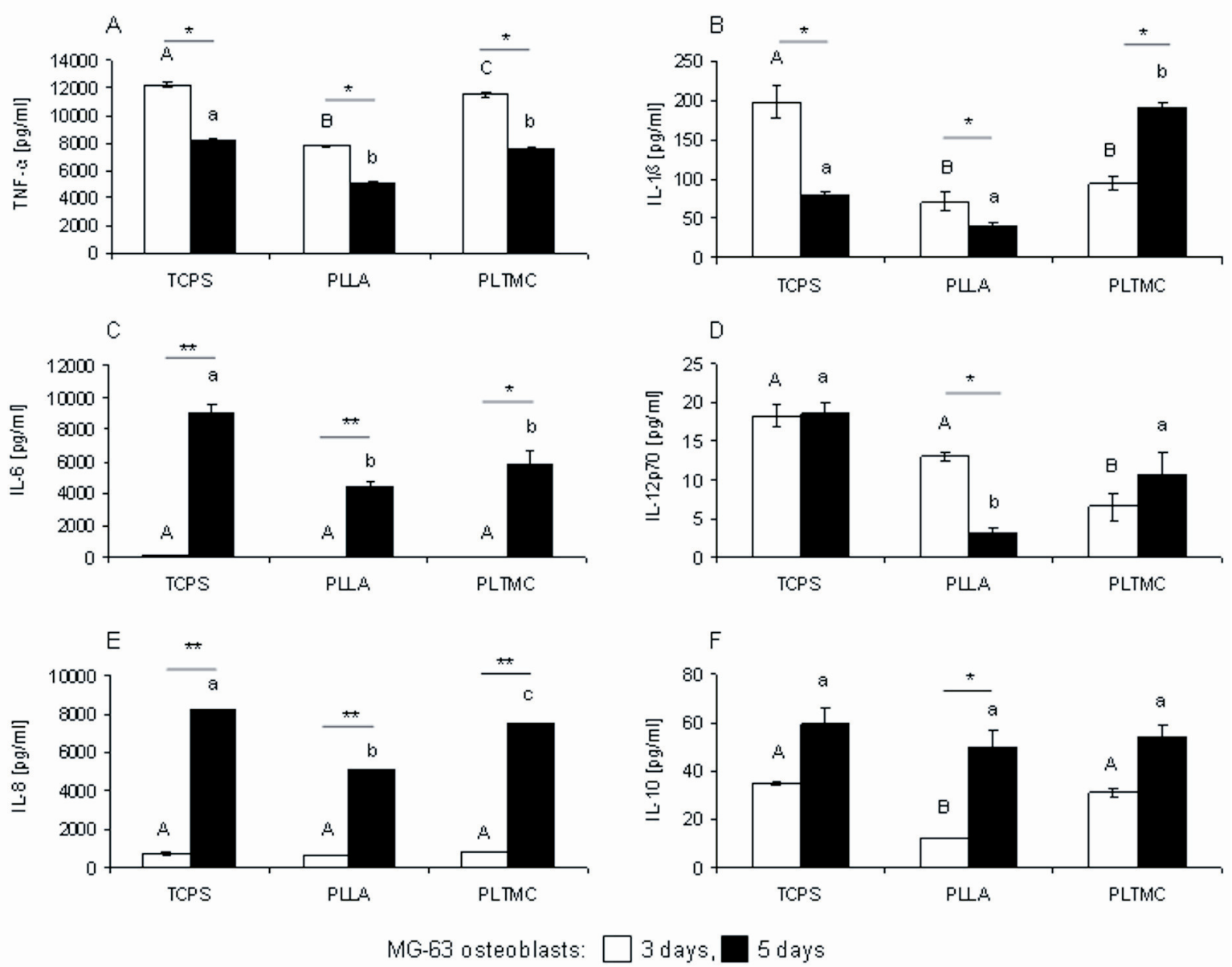

Fig. 5. Synthesis of pro- and anti-inflammatory cytokines by MG-63 osteoblasts in the presence of the tested polymers. Levels of pro-inflammatory cytokines (A) TNF- $\alpha$, (B) IL-1 $\beta$, (C) IL-6, (D) IL-12p70, (E) IL-8 and (F) IL-10 were measured in supernatants from MG-63 cells cultured on control tissue culture polystyrene (CTR) and on polymers: poly(L-lactide) (PLLA) and poly(L-lactide-co-trimethylene carbonate) (PLTMC) for 3 or 5 days. The results are presented as means SE. Different letters (e.g. A versus B or a versus b) indicate statistically significant differences between the groups according to ANOVA. Asterisks indicate statistical differences between day 3 and $5 * \mathrm{P}<0.05 ; * * \mathrm{P}<0.01$. 

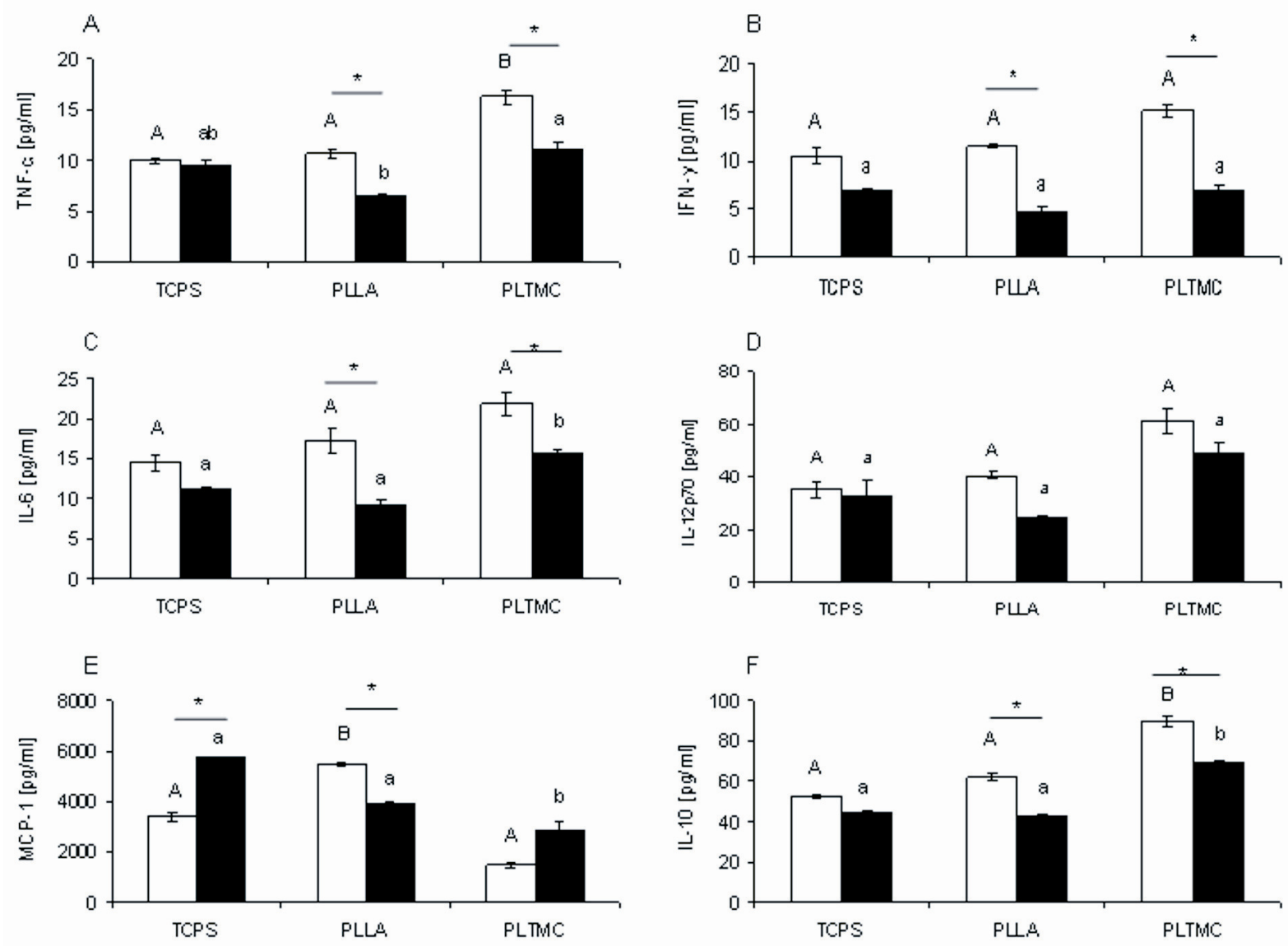

L-929 fibroblasts:

3 days,

5 days

Fig. 6. Synthesis of pro- and anti-inflammatory cytokines by L-929 fibroblasts in the presence of the tested polymers. Levels of pro-inflammatory cytokines (A) TNF-, (B) IFN-, (C) IL-6, (D) IL-12p70, (E) chemokine MCP-1, (F) IL-10 were measured in supernatants from L-929 cells cultured on control tissue culture polystyrene (CTR) and on polymers: poly(L-lactide) (PLLA) and poly(L-lactide-co-trimethylene carbonate) (PLTMC) for 3 or 5 days. The results are presented as means SE. Different letters (e.g. A versus $\mathrm{B}$ or a versus b) indicate statistically significant differences between the groups according to ANOVA. Asterisks indicate statistical differences between day 3 and $5 * \mathrm{P}<0.01 ; * * \mathrm{P}<0.01$.

days 3 and 5, respectively (Fig. 5D). In comparison to the control, production of anti-inflammatory IL-10 was significantly lower in the presence PLTMC on day 3 only (Fig. 5F).

\section{Cytokine production by L-929}

In the presence of PLTMC secretion of proinflammatory IL- 6 and TNF- $\alpha$ increased on day 5 and on day 3, respectively (Fig. 6C). Enhanced synthesis of the chemokine MCP-1 was detected on day 3 in the presence of PLLA, but was lower in 5-day cultures with PLTMC, in comparison to TCPS (Fig 6E). Incubation of fibroblasts with PLLA and PLTMC did not have a significant effect on IFN- $\gamma$ (Fig. 6B) and IL-12p70 (Fig. 6D) synthesis/release on days 3 and 5 in comparison to the control. PLTMC significantly increased synthesis of anti-inflammatory IL-10 on both investigated days (Fig. 6F).

\section{Discussion}

Orchestrated interactions between the cellular milieu and biomaterial are required for the proper functioning of the material, incorporation into the body tissue, as well as its resistance to tissue damage induction or infection (BARBUL 1990; HENKE et al. 1998). The two latter processes are collectively known as inflammation and the occurrence of either leads to leukocyte activation and production of pro-inflammatory mediators (reactive oxygen species, cytokines/chemokines) which in the least favorable situation might induce biomaterial rejection because of low biocompatibility (MAJNO $\&$ JORIS 2004). In line with this, adequate structural/stromal cell functioning is essential for the normal healing and tissue integration of the implanted biomaterial, and elevation of pro- 
inflammatory mediators may affect local tissue homeostasis.

Here we show that the two tested polymers, PLLA and PLTMC, compared to the reference TCPS differentially affect fibroblasts/osteoblasts. In particular, we detected that in the case of both cell populations adhesion onto polymeric surfaces was better on PLLA than on PLTMC or TCPS. This effect might be explained by some properties of these materials as they vary in surface topography and characteristics due to differences in their chemical structure (compare Fig. 1). In particular, both polyesters are rather textured but the average surface roughness of PLTMC is lower than that of PLLA; and such properties were reported to support proper cell adherence (SCISLOWSKA-CZARNECKA et al. 2012). The behavior of cells in contact with the material, especially with its surface, relates directly to its biocompatibility (ANSELME 2000; CHOU et al. 1995). This is because the quality of the first cell-material contact influences the capacity to proliferate and function at the material/biological milieu interface. The test used by us for adherence utilizes crystal violet (a cytochemical stain that binds to chromatin) and the assay is also considered as an indirect measurement of cell proliferation (CHATURVEDI et al. 2007). Thus, from this point of view, PLLA seems to be the most preferable for either fibroblast or osteoblast proliferation. Nevertheless, it should be pointed out that both cell types adhered and proliferated on the PLLA and PLTMC surfaces maintaining their characteristic morphology (not shown). However, the polymers were not irrelevant for the tested cell populations because significantly increased apoptosis of both cell types was detected on either day 3 or day 5. Especially on day 5, up to one third of the tested cells was apoptotic in the presence of either PLLA or PLTMC; this value was not higher than $5 \%$ for TCPS. Among the dying cells, the majority was just entering the death pathway (early apoptotic cells; Annexin $\mathrm{V}^{+} / 7-\mathrm{AAD}^{-}$) which means these were not cells that died some hours/days before and accumulated in the culture dish but were dying in real time. The induction of apoptosis might be a consequence of the cytotoxicity of the material and has been observed in previous studies, e.g. when the effects of poly(L-lactide) were tested on macrophages (TH-1 cell line) (POTNIS et al. 2011). We have also observed that PLLA and PLTMC affected macrophage (RAW.264 cell line) viability as demonstrated by evaluation of apoptotic cells (SCISLOWSKA-CZARNECKA et al. 2012). Thus it seems that both polymers show some level of cytotoxicity towards different types of cells when cultured in different conditions.

The appearance of a foreign body in a living organism provokes an inflammatory response aimed at eliminating it by means of multiple proinflammatory mediators (MAJNO \& JORIS 2004; REUTER et al. 2011). During the so called respiratory burst, different reactive oxygen species are generated that might evoke a cascade of signals leading to several intracellular events, including apoptosis (BAYIR \& KAGAN 2008). For this we tested the production of $\mathrm{NO}$ that might impact the cell cycle by inhibiting electron transport chain complexes in mitochondria (PROTTI \& SINGER 2006). We observed some correlation between the release of $\mathrm{NO}$ and the ratio of apoptosis, i.e. enhanced apoptosis was accompanied by higher NO levels detected in supernatants from L-929 fibroblasts when they were cultured with PLTMC for 5 days. However, PLTMC lowered NO release by osteoblasts and also PLLA had a down-regulating effect on both cell populations in terms of NO production. Therefore a direct association between NO production and the rate of apoptosis in the tested system cannot be postulated. Limited data is available on nitric oxide release by cells cultured in the presence of PLLA and PLTMC but for example, in a study by Liu and co-workers (2010), human umbilical vein endothelial cells (HUVECs) cultured on poly(D,L-lactide) were also stimulated to synthesize NO (LIU et al. 2011).

In physiological conditions fibroblasts and osteoblasts produce differential factors, including growth factors and MMPs (CAETANO-LOPES et al. 2009; ENZERINK \& VAHERI 2011) but their activity might change upon biomaterial implantation. We show that the release of proteins (measured as their total content in supernatants) by either cell population was altered by the polymers. In the case of osteoblasts the two materials, and especially PLTMC, rather decreased protein synthesis. The effect on fibroblasts was less coherent, PLTMC increased protein release on both days of culture while PLLA enhanced it on day 3 but decreased it on day 5. Moreover, we revealed that levels of cytokines/chemokines were particularly affected. In particular, PLLA down-regulated the synthesis of numerous cytokines on day 3 (TNF- $\alpha$, IL-1 $\beta$, IL-10) and 5 (TNF- $\alpha$, IL-6, IL-8, IL-12) by osteoblasts while in most cases it had no effect on fibroblast cytokine release, except of transiently (on day 3 only) enhanced MCP-1 production. This is in line with data on total protein synthesis in the presence of PLLA which generally decreased in the osteoblast cultures on day 5 but was higher on day 3 in the fibroblast cultures. Thus the above data suggest that PLLA shows only a moderate enhancing effect on the synthesis of proinflammatory cytokines/chemokines. On the other hand, in the case of PLTMC this is more complex because of the reduced production of some cytokines (e.g. TNF- $\alpha$, IL-6, IL-8, IL-12) in osteoblasts in the presence of this polymer, although the syn- 
thesis of potent IL- $1 \beta$ was differentially affected (lower on day 3 but higher on day 5). Moreover, PLTMC enhanced the production of pro-inflammatory TNF- $\alpha$ and IL- 6 and anti-inflammatory IL-10 by fibroblasts, therefore revealing an overall more pro-inflammatory character than PLLA.

The two polymers also affected the synthesis of MMP-9. The main function of this protease is degradation of denatured collagens, including basement membrane collagens of type IV and as such the regulation of leukocytosis which is a highlight of the inflammatory response (OPDENAKKER et al. 2001). Only PLTMC increased MMP-9 production by fibroblasts which further suggests its potential pro-inflammatory behavior. Nevertheless, MMP-9 synthesis by fibroblasts was detected only on day 3, thus the unwanted impact of PLTMC should not have a long-term effect. On the other hand, both tested polymeric materials decreased MMP-9 release from osteoblasts on day 5 of culture. In the case of bone cells the role of MMP-9 is more complex as it cooperates with another gelatinase, MMP-2, in bone remodeling Therefore we can speculate that in our system the decrease of MMP-9 synthesis by osteoblasts might signal the possibility of impaired bone remodeling in the presence of PLLA and PLTMC.

In general, the results on mediator production indicate that the inflammatory response induced in the presence of PLTMC is rather strong and could activate leukocytes. In contrast, the impact of PLLA was much more moderate as only the production of chemokine MCP-1 was transiently elevated in fibroblasts. However, MCP-1 is a known monocyte/macrophage factor attracting those cells to the site of foreign body invasion/implantation (AJUEBOR et al. 1998). The communication between fibroblasts and macrophages, both being the primary effector cells in the response to a foreign body, is well documented and involves soluble factors and direct cell-cell contacts (HOLT et al. 2011). The two cell types might also be coinvolved in implant degradation and fibrosis. In line with this we showed previously that PLTMC, but not PLLA, increased synthesis of pro-inflammatory IFN- $\gamma$ and IL-12p70 by macrophages in vitro (SCISLOWSKA-CZARNECKA et al. 2012).

In the majority of previous studies PLTMC was reported to be a biocompatible and biodegradable material. For example, Pego and co-workers (2003) have used different copolymers of PLTMC ( 20 or $50 \mathrm{~mol} \%$ of 1,3 -trimethylene carbonate) to develop three-dimensional scaffolds for soft tissue engineering. Their in vitro cell seeding studies showed that rat cardiomyocyte cells attached and proliferated well on this copolymer (PEGO et al. 2002; PEGO et al. 2003a). Moreover, PLTMC had good resorption properties in vivo, and only a mild tissue response was observed (PEGO et al. 2003b, PEGO et al. 2003c).

However, it should be pointed out that in the above study as well as in other numerous reports only limited immunological parameters (if any) were studied. For example, MUKHERJEE and coworkers (2011) provide an investigation of the biological effects of PLTMC (70:30) on myocardial cells that was limited to their proliferation, morphology and specific cell markers. A similar approach was undertaken by Ji and colleagues (2010) when studying the effects of PLTMC $(85: 15)$ on mouse NIH/3T3 fibroblasts (Ji et al. 2010). Both studies described improved adherence of the investigated cells although no immunological parameters were evaluated while, as revealed in our studies, the cells might adhere in an uncompromised manner and yet be active in the potent immune response (MUKHERJEE et al. 2011; Ji et al. 2010).

One of the few studies in which immunological parameters were evaluated was performed in vivo and PLTMC/PLLA were implanted subcutaneously (GUO et al. 2011). Fewer immune cells infiltrated tissues around PLTMC than in the PLLA implanted rats (GUO et al. 2011). However, some macrophage infiltration was observed in a study in which the polymers were implanted into rat peritoneal cavity (DARGAVILLE et al. 2011).

On the other hand, a small number of studies revealed that PLTMC might have some significantly unfavorable effects on the investigated cells/tissues. One of the most important of them is a clinical follow-up case study reporting delayed foreignbody reaction to absorbable implants, including those consisting of trimethylene carbonate and L-lactide (GIVISSIS et al. 2010). The study reveals that the implanted polymers achieved adequate bone healing. Although at first no foreign-body (inflammatory) reaction was observed, it was postponed and occurred after a few years; requiring is some cases implant removal (GIVISSIS et al. 2010). In in vitro settings, the adverse effects of PLTMC were shown previously by our group in relation to macrophages RAW 264.7. We demonstrated that the polymer decreased their adherence, increased production of NO, MMP-9 and pro-inflammatory cytokines (SCISLOWSKA-CZARNECKA et al 2012).

Overall, the data presented here suggest that in the case of fibroblasts and osteoblasts, PLTMC acts as a stronger immunostimulator than PLLA leading to the generation of reactive oxygen species and cytokines/chemokines. In addition, although PLTMC is associated with rather good cell adhesion, it is a more severe inducer of fibroblast and osteoblast apoptosis than PLLA. Therefore 
based on our in vitro studies we can conclude that the copolymerization of L-lactide with trimethylene carbonate (50:50) does not result in polymeric material with improved cytocompatibility, as estimated by its ability to activate the immune system, at least towards fibroblasts and osteoblasts in our in vitro system.

\section{Acknowledgments}

The authors acknowledge Miss Aleksandra TLALKA's assistance with the zymographic analyses and Prof. Piotr DOBRZYNSKI for the synthesis of PLTMC.

\section{References}

AJUEBor M. N., Flower R. J., HANNON R., CHRISTIE M., Bowers K., Verity A., PerRetTi M. 1998. Endogenous monocyte chemoattractant protein-1 recruits monocytes in the zymosan peritonitis model. J. Leukoc. Biol. 63: 108-116.

ANSELME K. 2000. Osteoblast adhesion on biomaterials. Biomaterials 21: 667-681.

BARBUL A. 1990. Immune aspects of wound repair. Clin. Plast. Surg. 17: 433-442.

BA YIR H., KAGAN V. E. 2008. Bench-to-bedside review: Mitochondrial injury, oxidative stress and apoptosis - there is nothing more practical than a good theory. Crit. Care $\mathbf{1 2}$ 206.

CAetano-Lopes J., Canhao H., Fonseca J. E. 2009. Osteoimmunology - the hidden immune regulation of bone. Autoimmun. Rev. 8: 250-255.

CAMERon D. J., Shaver M. P. 2011. Aliphatic polyester polymer stars: synthesis, properties and applications in biomedicine and nanotechnology. Chem. Soc. Rev. 40 1761-1776

Chaturvedi L. S., Marsh H. M., Basson M. D. 2007. Src and focal adhesion kinase mediate mechanical straininduced proliferation and ERK1/2 phosphorylation in human H441 pulmonary epithelial cells. Am. J. Physiol. Cell Physiol. 292: C1701-1713.

Chou L., Firth J. D., Uitto V. J., BRunette D. M. 1995. Substratum surface topography alters cell shape and regulates fibronectin mRNA level, mRNA stability, secretion and assembly in human fibroblasts. J. Cell Sci. 108: $1563-1573$

Dargaville B.L., Vaquette C., Peng H., Rasoul F., CHAU Y.Q., COOPER-White J. J., CAMPBELL J. H., WHiTTAKER A. K. 2011. Cross-linked poly(trimethylene carbonate-co-L-lactide) as a biodegradable, elastomeric scaffold for vascular engineering applications. Biomacromolecules 12: 3856-69.

DOBRZYNSKI P., KASPERCZYK J., JELONEK K., RYBA M., WALSKI M., BERO M. 2006. Application of the lithium and magnesium initiators for the synthesis of glycolide, lactide, and epsilon-caprolactone copolymers biocompatible with brain tissue. J. Biomed. Mater. Res. A 79: 865-873.

ENZERINK A., VAHERI A. 2011. Fibroblast activation in vascular inflammation. J. Thromb. Haemost. 9: 619-626.

Givissis P. K., Stavridis S. I., PaPagelopoulos P. J., AntonaraKos P. D., Christodoulou A. G. 2010. Delayed foreign-body reaction to absorbable implants in metacarpal fracture treatment. Clin. Orthop. Relat. Res. 468 3377-83.
Gunatillake P., MayadunNe R.,ADHIKARI R. 2006. Recent developments in biodegradable synthetic polymers. Biotechnol. Annu. Rev. 12: 301-347.

GUO Q., ZHIQIAN L., ZHANG Y., LI S., YoldMAN J. 2011. In vivo study on the histocompatibility and degradation behavior of biodegradable poly(trimethylene carbonate-co-D, Llactide). Acta Biochim. Biophys. Sin. 43: 433-440.

HeNKE P. K., BERGAMINI T. M., WATSON A. L., BRitTIAN K. R., POWELl D. W., PEYTON J. C. 1998. Bacterial products primarily mediate fibroblast inhibition in biomaterial infection. J. Surg. Res. 74: 17-22.

HOLLINGER J. O. 1983. Preliminary report on the osteogenic potential of a biodegradable copolymer of polyactide (PLA) and polyglycolide (PGA). J. Biomed. Mater. Res. 17: 71-82.

Holt D. J., Chamberlain L. M., Grainger D. W. 2011. Cell-cell signaling in co-cultures of macrophages and fibroblasts. Biomaterials 31: 9382-9394.

HUA J. J., GEBAROWSKA K., DOBRZYNSKI P., KASPERCZYK J., WEI J., LI S. M. 2009. Influence of chain microstructure on the hydrolytic degradation of copolymers from 1,3-trimethylene carbonate and L-Lactide. J. Polym. Sci. A. Polym. Chem. 47: 3869-3879.

Ji L. J., LAI K. L., He B., WOLDMAN G., SONG L. Q., WU Y., Gu Z. W. 2010. Study on poly(L-lactide-co-trimethylene carbonate): synthesis and cell compatibility of electrospun film. Biomed. Mater. 5: 1-8.

KolaczKowska E., BarteczKo M., Plytycz B., ARnold B. 2008. Role of lymphocytes in the course of murine zymosan-induced peritonitis. Inflamm. Res. 57: 272-278.

KolaczKowsKa E., ChadZinska M., SCISLOW SKa- CZARNECKA A., PLYTYCZ B., OPDENAKKER G., ARNOLD B. 2006. Gelatinase B/matrix metalloproteinase-9 contributes to cellular infiltration in a murine model of zymosan peritonitis. Immunobiology 211: 137-148.

KolaczKowska E., KozIOl A., Plytycz B., ARnold B., OPDENAKKER G. 2009. Altered apoptosis of inflammatory neutrophils in MMP-9-deficient mice is due to lower expression and activity of caspase-3. Immunol. Lett. 126: 73-82.

KolaczKowsKa E., Plytycz B., ANORld B., PicCard H., OPDENAKKER G. 2009a. Increased cyclooxygenase activity impairs apoptosis of inflammatory neutrophils in mice lacking gelatinase $\mathrm{B} /$ matrix metalloproteinase-9. Immunology 128: $262-274$.

Lendlein A., Neffe A. T., Pierce B. F., Vienken J. 2011. Why are so few degradable polymeric biomaterials currently established in clinical applications? Int. J. Artif. Organs 34: 71-75.

LEWANDOWSKA-SZUMIEL M., WoJTOWiCZ J. 2011. Bone tissue engineering - a field for new medicinal products? Curr. Pharm. Biotechnol. 12: 1850-859.

LiU Y., WANG W., WANG J., WANG Y., YUAN Z., TANG S., LIU M., TANG H. 2011. Blood compatibility evaluation of poly(D,L-lactide-co-beta-malic acid) modified with the GRGDS sequence. Colloids Surf. B Biointerfaces 75: 370-376.

MAJNO G., JORIS I. 2004. Cells, tissues, and disease: principles of general pathology. Blackwell, Oxford. pp. XXVIII, 1005.

MukHER.JeE S., Gualandi C., Focarete M. L., RAVICHANDRAN R., VENUGOPAL J. R., RAGHUNATH M., RAMAKRISHNA S. 2011. Elastomeric electrospun scaffolds of poly(L-lactide-co-trimethylene carbonate) for myocardial tissue engineering. J. Mater. Sci. Mater. Med. 22: $1689-1699$

Nelson J., Stanford H. G., CUTRIGHT D. E. 1977. Evaluation and comparisons of biodegradable substances as osteogenic agents. Oral Surg. Oral Med. Oral Pathol. 43: 836-843.

OPDENAKKER G., VAN DEN STEEN P. E., DUBOIS B., NELISSEN I., VAN COILlie E., MASURE S., ProOst P., VAN DAMME J. 2001. Gelatinase B functions as regulator and effector in leukocyte biology. J. Leukoc. Biol. 69: 851-859. 
Palm M. D., Goldman M. P. 2009. Patient satisfaction and duration of effect with PLLA: a review of the literature. J. Drugs Dermatol. 8: s15-20.

Pang X., Zhuang X., TANG Z., Chen X. 2011. Polylactic acid (PLA): research, development and industrialization. Biotechnol. J. 5: 1125-1136.

PEGO A.P., POOT A.A., GRIJPMA D.W., FEIJEN J. 2003. Biodegrable elastomeric scaffolds for soft tissue engineering. J. Controlled Release 87: 69-79.

Pego A. P., Poot A. A., GRiJPMA D. W., FeiJen J. 2003a. Physical properties of high molecular weight 1,3 trimethylene carbonate and D,L-Lactide copolymers. J. Mater. Sci.: Mater. Med. 14: 767-773.

Pego A.P ., Poot A. A., GRiJPMA D. W., FeIJEN J. 2002. In vitro degradation of trimethylene carbonate based (co) polmers. Macromol. Biosci. 2: 411-420.

Pego A. P., Siebum B., VAn Luyn M. J., Gallegoy Van SeiJen X. J., PoOt A. A., GRIJPMA D. W., FEIJEN J. 2003b. Preparation of degradable porous structures based on 1,3trimethylene carbonate and D,L-Lactide (Co)polymers for heart tissue engineering. Tissue Eng. 9: 981994.

Pego A. P., VAN LuYN M. J., Brouwer L. A., VAN WACHEM P. B., POOT A. A., GRIJPMA D. W., FEIJEN J. $2003 \mathrm{c}$. In vivo behavior of poly(1,3-trimethylene carbonate) and copolymers of 1,3-trimethylene carbonate with D,Llactide or epsilon-caprolactone: Degradation and tissue response. J. Biomed. Mater. Res. A 67: 1044-1054.

Potnis P. A., Tesfamariam B., WoOD S. C. 2011. Induction of nicotinamide-adenine dinucleotide phosphate oxidase and apoptosis by biodegradable polymers in macrophages: implications for stents. J. Cardiovasc Pharmacol. 57: 712-720.

PRotTi A., Singer M. 2006. Bench-to-bedside review: potential strategies to protect or reverse mitochondrial dysfunction in sepsis-induced organ failure. Crit. Care 10: 228.

Reuter S., Gupta S. C., Chaturvedi M. M., Aggarwal B. B. 2011. Oxidative stress, inflammation, and cancer: how are they linked? Free Radic Biol. Med. 49: 1603-1616.

Scislowska-CZarnecka A., Pamula E., Tlalka A., KOLACZKOWSKA E. 2012. Effects of aliphatic polyesters on activation of the immune system: studies on macrophages. J. Biomater Sci. Polym. Ed. 23: 715-738.

SHASTRI V. P., LENDLEIN A. 2009. Materials in regenerative medicine. Adv. Mater 21: 3231-3234.

VAN SLIEDREGT A., VAN LOON J. A., VAN DER BRINK J., DE GROOT K., VAN BLITTERSWIJK C. A. 1994. Evaluation of polylactide monomers in an in vitro biocompatibility assay. Biomaterials 15: 251-256.

VERHEYEN C. C., DE WiJn J. R., VAN BLITTERSWiJK C. A., ROZING P. M., DE GROOT K. 1993. Examination of efferent lymph nodes after 2 years of transcortical implantation of poly(L-lactide) containing plugs: a case report. J. Biomed. Mater Res. 27: 1115-1118.

Yaszay B., TRindade M. C., Lind M., GoOdMan S. B., SMITH R. L. 2001. Fibroblast expression of C-C chemokines in response to orthopaedic biomaterial particle challenge in vitro. J. Orthop. Res. 19: 970-976.

Zhang Z., KuiJer R., Bulstra S. K., GRiJPMa D. W., FEIJEN J. 2006. The in vivo and in vitro degradation behavior of poly(trimethylene carbonate). Biomaterials 27: 1741-1748. 